\title{
Emulsifying Properties of Hydrolysates Isolated from Soybean Protein
}

\author{
Luis Alberto Panizzolo ${ }^{1}$, María Cristina Añón ${ }^{2}$ \\ ${ }^{1}$ Departamento de Ciencia y Tecnología de Alimentos, Facultad de Química, Universidad de la República, Montevideo, Uruguay \\ ${ }^{2}$ Centro de Investigación y Desarrollo en Criotecnología de Alimentos (CIDCA), CONICET, Facultad de Ciencias Exactas, Universidad \\ Nacional de La Plata, La Plata, Argentina
}

Email address:

apanizzo@fq.edu.uy (L. A. Panizzolo)

\section{To cite this article:}

Luis Alberto Panizzolo, María Cristina Añón. Emulsifying Properties of Hydrolysates Isolated from Soybean Protein. International Journal of Nutrition and Food Sciences. Vol. 4, No. 2, 2015, pp. 223-233. doi: 10.11648/j.ijnfs.20150402.24

\begin{abstract}
We have developed new surfactant agents based on hydrolyzed soybean proteins using papain, and we have studied their ability to form and stabilize emulsions. The interfacial behavior and the emulsifying properties were correlated to the structural changes that the proteins underwent. The hydrolysis reaction was stopped by dropping to $\mathrm{pH} 2$ in one case, or rapidly dropping the temperature to $-18^{\circ} \mathrm{C}$ in the other. The structural and functional properties of the obtained products depended on the way the papain hydrolysis of the soy proteins was stopped. Hydrolysis did not have a beneficial effect on the emulsifying properties of those hydrolysates that were stopped by freezing. For all the degrees of hydrolysis we studied, the emulsifying properties of the isolates were significantly improved when the hydrolysis reaction was stopped by dropping to $\mathrm{pH} 2$.
\end{abstract}

Keywords: Soy Protein, Enzymatic Hydrolysis, Emulsion Properties

\section{Introduction}

Soy proteins in numerous and diverse food products. They have a great potential to substitute meat and dairy products considering their high digestibility and their well-balanced amino-acid composition. Nevertheless, over $95 \%$ of it is used as animal feed [1]. One of the main uses in human foodstuffs is as a functional ingredient, owing to its ability to form and stabilize gels, emulsions and foams [1]. Despite its commercial importance, the basic knowledge on the emulsifying properties of soy proteins has been scarce compared to their gelifying properties [2].

A restrained proteolysis may have positive effects on the surface activity of these proteins and hence on their emulsifying properties [3]. Studies on the modification of soy proteins by papain hydrolysis and its consequences on structural changes and functional properties of the modified proteins have been made in the past [4],[5]. However, in recent years there has been great progress in the methods and techniques for analyzing the formation and stability of emulsions, allowing for new studies and approaches that help to elucidate how the functional surface properties are linked to the structural characteristics of proteins. Furthermore, more research is needed to improve the functional properties of proteins, especially soy proteins, at $\mathrm{pH}$ ranges above than 4.0 , so that the use of these proteins in food systems becomes more widespread[1].

In that regard, our goal was to study the emulsion-forming and emulsion-stabilizing properties of the obtained hydrolyzed products, and establish how the interfacial behavior and emulsifying properties of these new surfactant agents relate to the way the hydrolysis reaction is interrupted.

\section{Materialsy Methods}

\subsection{Preparation of the Soy Protein Isolate}

The soy protein isolates (SPIs) were prepared by isoelectric precipitation $(\mathrm{pH} 4.5)$ of an aqueous solution (alkaline medium at $\mathrm{pH} 8.0$ ) of defatted soybean meal, which was then re-dispersed in an alkaline medium $(\mathrm{pH} \mathrm{8.0)}$ and freeze-dried [6].

\subsection{Preparation of the Hydrolysates}

The soy protein isolate (about $30 \mathrm{mg}$ of solid per $\mathrm{mL}$ ) was incubated with papain enzyme solution $(0.2 \mathrm{mg}$ of papain per 
$\mathrm{mL})$, at a $4: 1(\mathrm{v} / \mathrm{v})$ ratio, in a thermostatic water bath with continuous stirring at $40^{\circ} \mathrm{C}$. SPIs with protein contents of $90.8 \pm 0.4 \mathrm{~g} / 100 \mathrm{~g}, 3.50 \pm 0.02 \mathrm{~g} / 100 \mathrm{~g}$ moisture and $5.7 \pm$ $0.02 \mathrm{~g} / 100 \mathrm{~g}$ minerals (ash) were used. Papain (from Sigma) contained 28 units/mg (one enzyme unit hydrolyzes $1.0 \mu \mathrm{mol}$ of $\alpha$-N-benzoyl-L-arginine ethyl ester (BAEE) per minute at $\mathrm{pH} 6.2$ and $25^{\circ} \mathrm{C}$ ). The solutions or dispersions of the substrates were prepared in a $\mathrm{pH} 8.0$ buffer $(0.01 \mathrm{M}$ sodium phosphate). Different times for the hydrolysis treatment were used to obtain different degrees of hydrolysis(0. $1.8-2.5$ and $6.0 \%$ ). The hydrolysis reaction was stopped by: 1) dropping the $\mathrm{pH}$ of the soy protein isolate hydrolyzates (SPIH) to $\mathrm{pH} 2$ with $6 \mathrm{~N}$ hydrochloric acid $(\mathrm{HpH})$, and 2) rapid temperature drop of the SPIH dispersion using acooling bath(ice-sodium chloride bath) at $-18^{\circ} \mathrm{C}(\mathrm{HC})$. Subsequently, the obtained SPIHs were freeze-dried. SPIHs with the same degree of hydrolysis and stopping method were obtained from SPIs belonging to the same batch.

\subsection{Determination of the Degree of Hydrolysis}

The degree of hydrolysis (DH) was determined by measuring the free amino groups by the trinitrobencensulphonic acid (TNBS) method [7] with modifications described by [8]. The determinations were done three times using an L-leucine standard curve and measuring the absorbance at $420 \mathrm{~nm}$.

\subsection{Preparation of the Emulsions of the Study}

25:75 (v/v) oil-in-water $(\mathrm{o} / \mathrm{w})$ emulsions were prepared using the different obtained hydrolysates, with 1.0 and 2.0 $\mathrm{mg} / \mathrm{mL}$ protein concentration, dissolved in $\mathrm{pH} 7,0.01 \mathrm{M}$ sodium phosphate buffer without $\mathrm{NaCl}$. The emulsions were prepared at room temperature in an Ultra-turrax T25 homogenizer using the $\mathrm{S} 25 \mathrm{~N}-10 \mathrm{G}$ dispersing element at $20,000 \mathrm{rpm}$ for one minute.

\subsection{Determination of the Mean Droplet Size in the Emulsions}

The droplet size analysis was made with emulsions prepared as previously described, with or without treatment with $\mathrm{pH}$ 8.0, $50 \mathrm{mM}$ Tris/ $\mathrm{HCl}$ solution containing a 1\% SDS solution at a 1:1 ratio[9]. A Malvern Mastersizer Micro particle size analyzer was used to determine the $\mathrm{D}_{3.2}$ y $\mathrm{D}_{4.3}$ mean droplet diameters in a diameter interval ranging from 0.3 to $300 \mu \mathrm{m}$. The difference in the mean diameter values with or without the SDS solution was taken as a measurement of floccule or aggregate formation inside the emulsion (degree of flocculation) [9]:

$$
\mathrm{DoF}=\left[\left(\mathrm{D}-\mathrm{D}_{\mathrm{SDS}}\right) / \mathrm{D}_{\mathrm{SDS}}\right] \times 100
$$

Where DoF is the degree of flocculation, D is the mean diameter as determined in absence of SDS, and DSDS is the mean diameter as determined in presence of SDS.

The determinations were performed twice.

\subsection{Protein Concentration at the Interface}

The oil droplets were separated (washed) from the nonadsorbed proteins according to the method described by [10] and modifications by[11].The adsorbed and non-adsorbed protein concentrations were determined with the method used by [12].The protein concentration at the interface was calculated as:

$\Gamma\left(\mathrm{mg} / \mathrm{m}^{2}\right)=\left[\mathrm{P}_{\mathrm{a}}\right](\mathrm{mg} / \mathrm{mL}$ emulsion $) / \mathrm{Sv}\left(\mathrm{m}^{2} / \mathrm{mL}\right.$ emulsion $)(2)$

Where $\Gamma$ is the protein concentration at the interface, $\left[\mathrm{P}_{\mathrm{a}}\right]$ is the protein concentration adsorbed in the emulsion and $\mathrm{Sv}$ is the interface area.

The determinations were performed twice.

\subsection{Analysis of the Ability to form and Stabilize Oil-in- Water Emulsions}

All the emulsions were studied with an optical vertical scanner (Turbiscan). The creaming and destabilization kinetics of the emulsions were determined by measuring the backscattering value every minute for a total of 60 minutes, as well as a single measurement, 24 hours later. The creaming stability was studied based on the decrease in the meanbackscattering values in the lower part $(10-20 \mathrm{~mm}$, $\mathrm{BS}_{\mathrm{p} 10-20}$ zone) of the measurement tube versus time [13]. The destabilization kinetics was analyzed as suggested by [14] using the following equations:

$$
\begin{gathered}
\mathrm{BS}(\mathrm{t})=\mathrm{BS}_{\mathrm{h}} /\left(\mathrm{BS}_{\mathrm{h}} \mathrm{k}_{\mathrm{h}} \mathrm{t}+1\right) \\
\mathrm{BS}(\mathrm{t})=\mathrm{BS}_{\mathrm{h}} /\left(\mathrm{BS}_{\mathrm{h}} \mathrm{k}_{\mathrm{h}} \mathrm{t}+1\right)+\left(2^{2} \cdot \mathrm{BS}_{\mathrm{s}}\right) /\left[2^{2}+\left(\mathrm{k}_{\mathrm{s}} \cdot \mathrm{BS}_{\mathrm{s}}\right)^{2} \cdot \mathrm{t}^{2}\right]
\end{gathered}
$$

Where $B S(t)$ is the BS value at a time-point " $t$ ", $k_{h}$ is BS variation rate versus time constant for a second order kinetic model, $\mathrm{k}_{\mathrm{s}}$ is the $\mathrm{BS}$ variation rate versus time constant for a sigmoid-fit kinetic model, and $\mathrm{BS}_{\mathrm{h}}$ and $\mathrm{BS}_{\mathrm{s}}$ are the amplitude parameters for the aforementioned kinetic models, so thatBS $+\mathrm{BS}_{\mathrm{s}}=\mathrm{BS}_{i}$.

The overall destabilization of the emulsions was studied using the meanbackscattering values in the $50-53 \mathrm{~mm}$ area $\left(\mathrm{BS}_{\mathrm{p} 50-53}\right)$ versus time and the calculation of $\mathrm{D}(\%)[15]$ as follows:

$$
\mathrm{D}(\%)=\left[\left(\mathrm{BS}_{\mathrm{pmax} .}-\mathrm{BS}_{\mathrm{p} 24}\right) / \mathrm{BS}_{\mathrm{pmax}}\right] \mathrm{x} 100
$$

Where: $\mathrm{D}(\%)$ : overall degree of destabilization, $\mathrm{BS}_{\mathrm{pmax} \text { : }}$ mean of the maximumbackscattering value at a time-point in a given interval and $\mathrm{BS}_{\mathrm{p} 24 .}$. mean backscatteringat 24 hours in a given interval.

The determinations correspond to duplicates which were also assayed twice.

\subsection{Statistical Analysis}

The fixed-effects model of analysis of variance (ANOVA) was used for statistical treatment of data, with $\alpha=0.05$; followed by the comparison of mean values by the least significant differences (LSD) test, with $\alpha=0.05$, using Statgraphics plus 7.0 software. 


\section{Results and Discussion}

\subsection{Formation of the Emulsion}

\subsubsection{Particle Size Analysis}

The variation of the $\mathrm{D}_{3.2}$ and $\mathrm{D}_{4.3}$ values of the emulsions in presence of SDS and relative to the different variables under study is shown in Table 1 A marked difference between the $\mathrm{D}_{3.2}$ and $\mathrm{D}_{4.3}$ values of all assayed samples can be noted, which would indicate that the emulsions are polydisperse [16]. This can be seen in Figure1, where the amplitude of the particle size interval ranges from about 0.3 to $220 \mu \mathrm{m}$. All emulsions showed a modal distribution. Most of the oil volume corresponds to the peaks belonging to the higher droplet-size interval, whose diameter is generally above 10 $\mu \mathrm{m}$. However, Figures $1 \mathrm{~b}$ and $\mathrm{c}$ show that the diameter of the great majority of particles is below $10 \mu \mathrm{m}$, which would mean that about 60 to $80 \%$ of the emulsified oil volume is distributed among very few droplets, representing less than $0.05 \%$ of the total. Most of the newly-formed area percentage, about 70 to $85 \%$, was shown to correspond to the particle size interval below $10 \mu \mathrm{m}$, in line with the particle number distribution.

The degree of hydrolysis did not significantly affect $\mathrm{D}_{3.2}$ values (Table1). Emulsions that were prepared by $\mathrm{HpH}$ showed a significantly higher $D_{3.2}$ value than the corresponding $\mathrm{HC}$ emulsions.

The degree of hydrolysis did not significantly affect the $\mathrm{D}_{4.3}$ values (Table1). For those emulsions that were prepared by $\mathrm{HC}$, the values corresponding to $\mathrm{DH}: 0,1.8$, and $2.5 \%$ were significantly lower than that of $\mathrm{DH} 6 \%$, as shown in Figure 1a, where the distribution of volume for HC-DH $6 \%$ shows a peak beyond $100 \mu \mathrm{m}$, whereas the distribution of HC-DH $0 \%$ has already decreased by that particle size. On the other hand, in those emulsions prepared by $\mathrm{HpH}$ the effect of the degree of hydrolysison $\mathrm{D}_{4.3}$ was not detected. The emulsions prepared by $\mathrm{HpH}$ showed a significantly higher $\mathrm{D}_{4.3}$ value than their correspondingHC counterparts, except for DH 6\% where the opposite was true (Figure 1a).

Table 1. Mean $D_{3.2}$ and $D_{4.3}$ values of the studied emulsions, with and without SDS treatment and $\mathrm{DoF}\left(D_{3.2) \text {. }}\right.$

\begin{tabular}{llllll}
\hline \multirow{2}{*}{ SPIH } & With SDS & \multicolumn{4}{l}{ Without SDS } \\
\cline { 2 - 6 } & $\mathbf{D}_{\mathbf{3 . 2}}$ & $\mathbf{D}_{\mathbf{4 . 3}}$ & $\mathbf{D}_{\mathbf{3 . 2}}$ & $\mathbf{D}_{\mathbf{4 . 3}}$ & DoF (D $_{\mathbf{3 . 2}}$ \\
\hline HC-DH 0\% & $5.2 \pm 0.3$ & $23 \pm 1$ & $12.6 \pm 0.8$ & $44 \pm 4$ & $142 \pm 8$ \\
HC-DH 1.8\% & $5.2 \pm 0.3$ & $24 \pm 1$ & $12.1 \pm 0.8$ & $51 \pm 5$ & $133 \pm 8$ \\
HC-DH 2.5\% & $5.2 \pm 0.3$ & $24 \pm 1$ & $11.9 \pm 0.8$ & $54 \pm 5$ & $129 \pm 7$ \\
HC-DH 6.0\% & $4.9 \pm 0.3$ & $61 \pm 5$ & $10.2 \pm 0.8$ & $83 \pm 7$ & $108 \pm 7$ \\
HpH-DH 0\% & $11.3 \pm 0.4$ & $37 \pm 1$ & $11.1 \pm 0.4$ & $40 \pm 2$ & NF \\
HpH-DH 1.8\% & $12.5 \pm 0.4$ & $38 \pm 1$ & $12.0 \pm 0.4$ & $41 \pm 2$ & NF \\
HpH-DH 2.5\% & $10.1 \pm 0.4$ & $35 \pm 1$ & $12.6 \pm 0.4$ & $40 \pm 2$ & $25 \pm 1$ \\
HpH-DH 6.0\% & $9.9 \pm 0.4$ & $37 \pm 1$ & $12.6 \pm 0.4$ & $41 \pm 2$ & $27 \pm 1$ \\
\hline
\end{tabular}

NF: found no flocculation
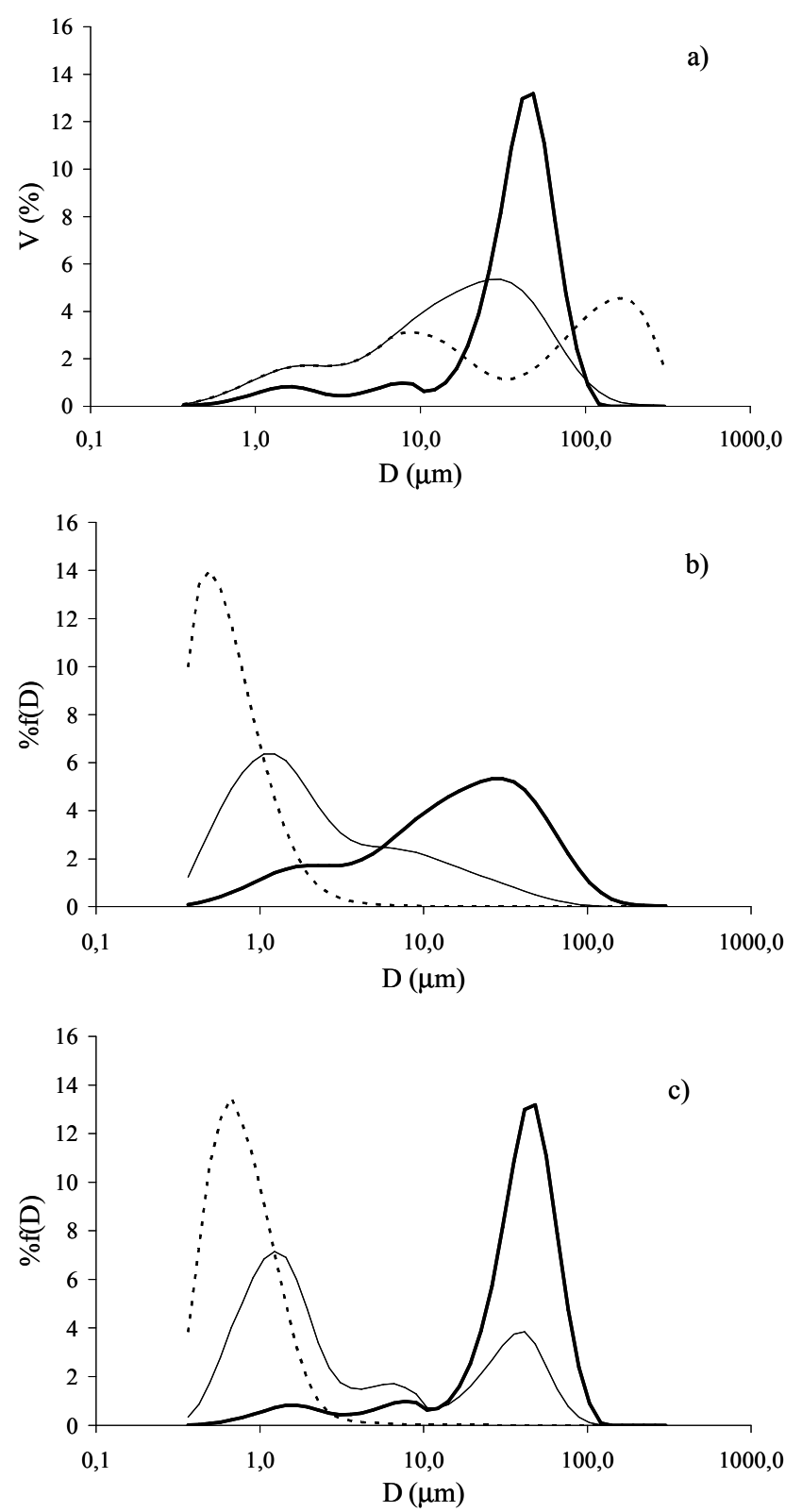

Figure 1. a) Droplet size distribution of the emulsions at $\mathrm{pH} 7.0$ and [ $\mathrm{NaCl}]$ $=0 \mathrm{M}$, with [protein] $=1 \mathrm{mg} / \mathrm{mL} \mathrm{HpH}-\mathrm{DH}=0 \%(-), H C-D H=0 \%(-\cdot)$ and $\mathrm{HC}-\mathrm{DH}=6 \%$ (...). The measurements were done in presence of SDS.b) Droplet size distributions of the emulsions at $\mathrm{pH} 7.0$ with $\mathrm{HC}-\mathrm{DH}=0 \%$ containing SDS, c) Droplet size distributions of the emulsions at pH 7.0 with $\mathrm{HpH}-\mathrm{DH}=0 \%$, with SDS. Volume (-), area (-) and number (...).

\subsubsection{Interfacial Protein Concentration}

The HpH samples showed greater $\Gamma$ values than the $\mathrm{HC}$ ones, the degree of hydrolysis only affected the $\mathrm{HpH}$ samples where DH $6 \%$ was significantly lower than the rest (Table 2). This could be attributed to two causes. Firstly, the $\mathrm{HpH}$ emulsions showed a greater adsorbed protein concentration at the interface for DH 0 and $1.8 \%$ (Table 2). Secondly, and probably most importantly, the $\mathrm{HC}$ emulsions showed a Sv value that was twice as much as those from $\mathrm{HpH}$ emulsions. 
Table 2. Interfacial protein concentration, interfacial area and adsorbed protein concentration in the studied emulsions.

\begin{tabular}{lll}
\hline SPIH Stopping method and DH & $\boldsymbol{\Gamma}\left(\mathbf{m g} / \mathbf{m}^{2}\right)$ & $\mathbf{S v}\left(\mathbf{m}^{2} / \mathbf{m l}\right.$ emulsion $)$ \\
\hline HC-DH 0\% & $1.7 \pm 0.1$ & $0.29 \pm 0.01$ \\
HC-DH 1.8\% & $1.5 \pm 0.1$ & $0.29 \pm 0.01$ \\
HC-DH 2.5\% & $1.7 \pm 0.1$ & $0.29 \pm 0.01$ \\
HC-DH 6.0\% & $1.3 \pm 0.1$ & $0.31 \pm 0.01$ \\
HpH-DH 0\% & $4.2 \pm 0.2$ & $0.14 \pm 0.01$ \\
HpH-DH 1.8\% & $4.2 \pm 0.2$ & $0.12 \pm 0.01$ \\
HpH-DH 2.5\% & $4.2 \pm 0.2$ & $0.12 \pm 0.01$ \\
HpH-DH 6.0\% & $3.3 \pm 0.2$ & $0.12 \pm 0.01$ \\
\hline
\end{tabular}

\subsubsection{Droplet Flocculation during Formation}

The addition of SDS, according to[9], produces the dissociation of any type of aggregate that may have formed in the emulsions by non-covalent interactions. Therefore, the mean measured diameters $\left(\mathrm{D}_{3.2}\right.$ and $\left.\mathrm{D}_{4.3}\right)$ in absence of SDS would indicate the droplets' tendency to flocculate through bridge formation. The variation of $\mathrm{D}_{3.2}$ and $\mathrm{D}_{4.3}$ values of the emulsions without SDS versus the different study variables, and the degree of flocculation of the studied emulsions is shown in Table1. The emulsions showed a modal distribution of the particle size (Figure 2) and great polydispersion, as observed in presence of SDS. $\mathrm{D}_{4.3}$ is the most sensitive to droplet aggregation of all the measured mean diameters[17]. The emulsions prepared by HC ([protein] $=1 \mathrm{mg} / \mathrm{mL}$ ) were the ones that showed the highest degree of flocculation of all the studied emulsion, particularly for DH $0,1.8$ y $2.5 \%$, whereas those prepared with $\mathrm{HpH}$ under different assayed conditions did not show flocculation through bridge formation or flocculated only slightly (not more than 13\%).

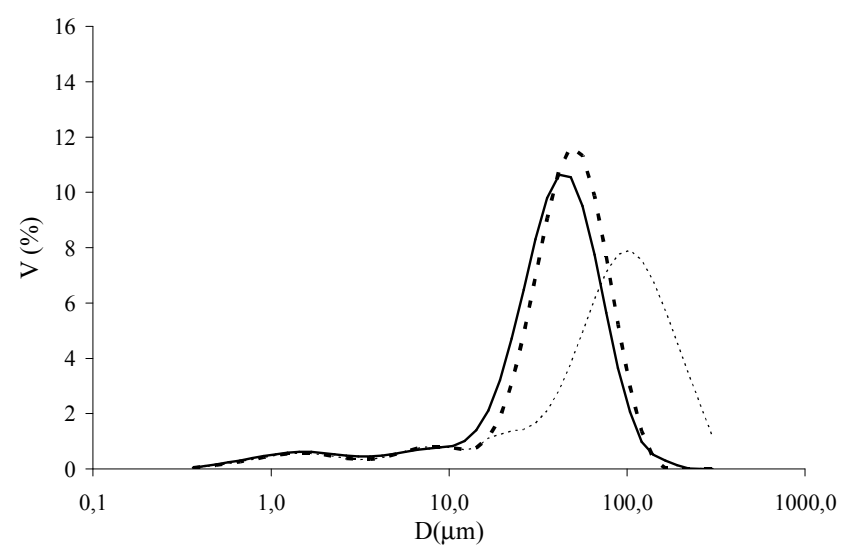

Figure 2. Droplet size distribution (in volume) of the emulsions at $\mathrm{pH} 7.0$ and $[\mathrm{NaCl}]=<0 \mathrm{M}$, with [protein] $=1 \mathrm{mg} / \mathrm{mL}$ of a) $\mathrm{HpH}-\mathrm{DH}=0 \%$ (一) b) $H C-D H=0 \%(-\cdots)$ y c) $H C-D H=6 \%$ (..). The measurements were performed in absence of SDS.

\subsection{Stability of the Emulsion}
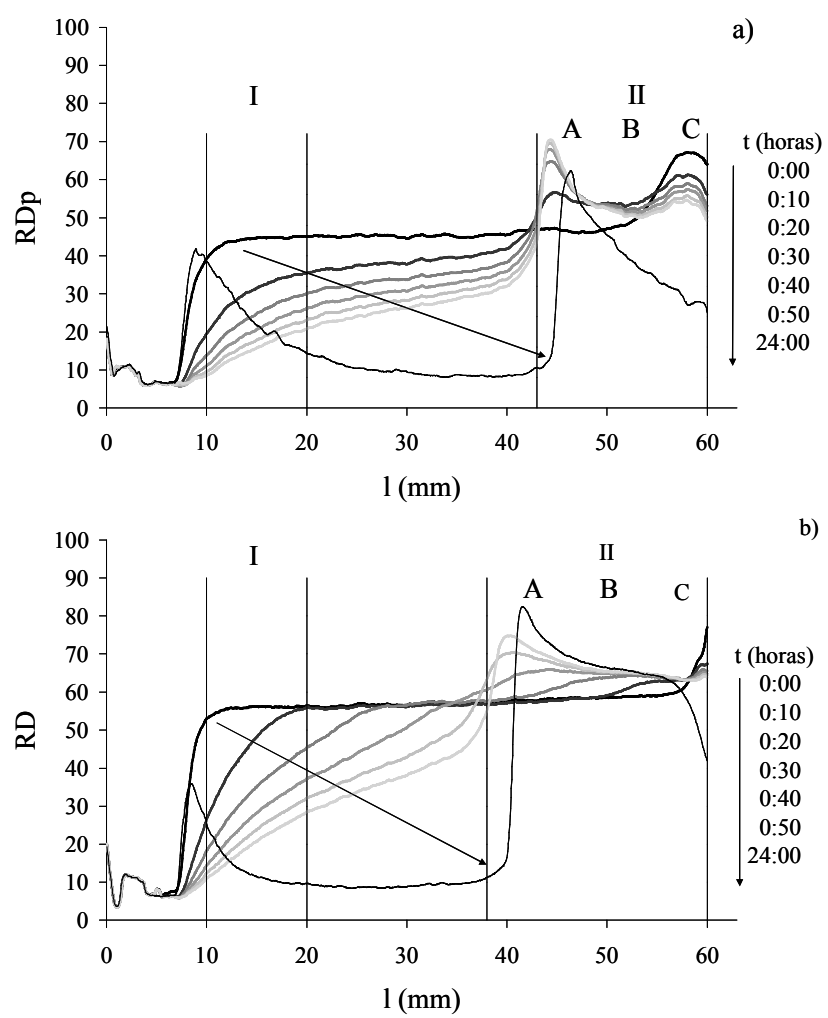

Figure 3. Backscattering profile for oil-in-water emulsions a) SPIHC and b) SPIHpH. The arrows show the profile's change versus time. Time is represented on the scale on the right.

Figures3 A and B show the backscattering (BS) versus the height profiles of the sample tube corresponding to $\mathrm{HC}$ and $\mathrm{HpH}$ emulsions respectively, where [protein] $=1 \mathrm{mg} / \mathrm{mL}, \mathrm{pH}$ 7.0 and $[\mathrm{NaCl}]=0 \mathrm{M}$.

For both emulsions, the lower part of the sample tube, i.e. zone I $(10-20 \mathrm{~mm})$, shows a decrease in the RD values over time, reflecting the development of a creaming process, and in zone II the cream phase can be observed, which stayed after the oil droplets accumulated in the upper part of the tube.

\subsubsection{Creaming Stability of the Emulsion}

Figure 4 shows the variation curves of the meanBS values $\left(\mathrm{BS}_{\mathrm{p}}\right)$ at the zone between $10-20 \mathrm{~mm}\left(\mathrm{BS}_{\mathrm{p} 10-20}\right)$ versus time, corresponding to all the assayed conditions of the emulsions.

It can be noted than some curves show a hyperbolic shape (e.g. Figure 4a) whereas other show a sigmoid shape (e.g. Figure $4 b$ ) 

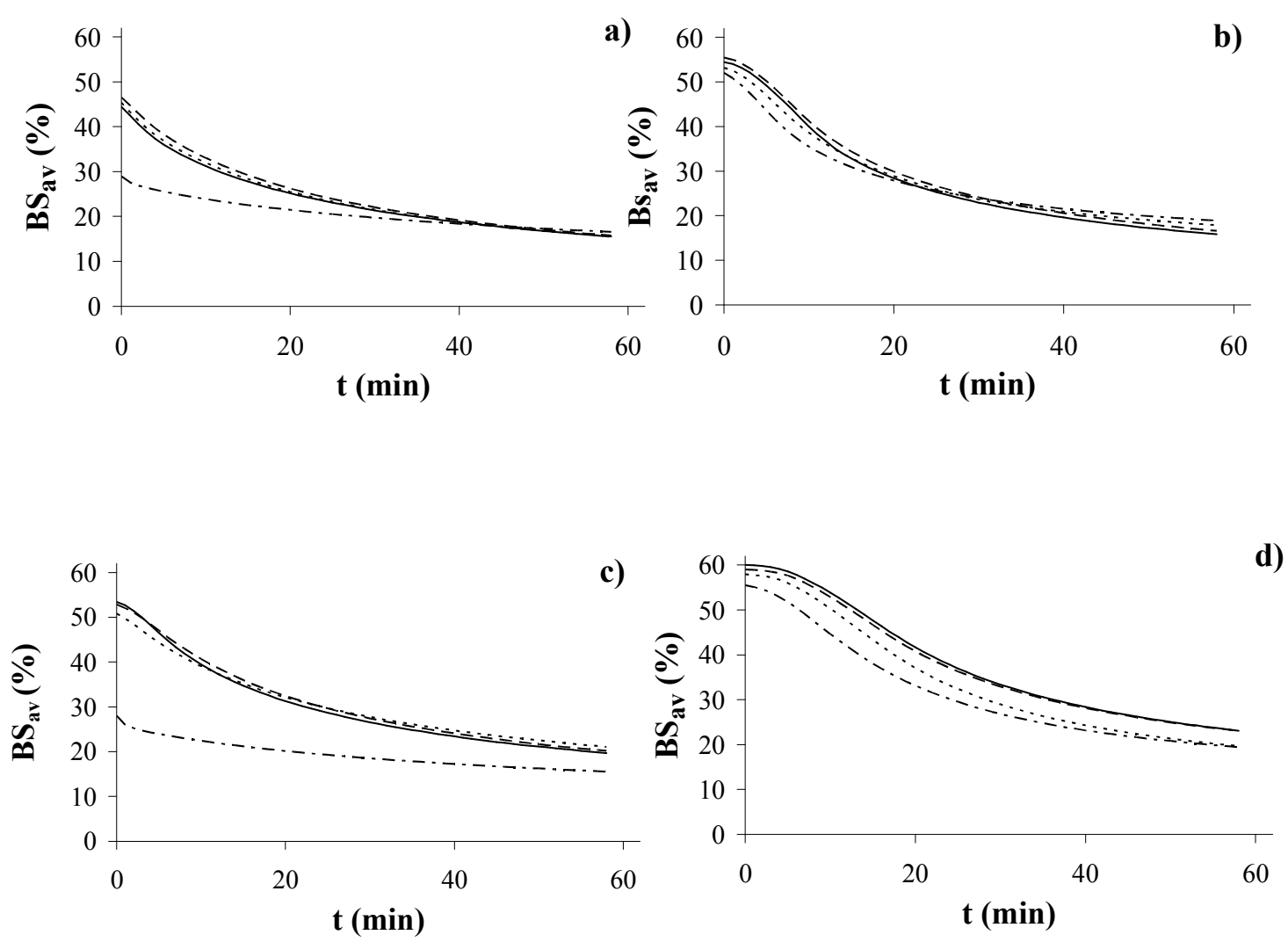

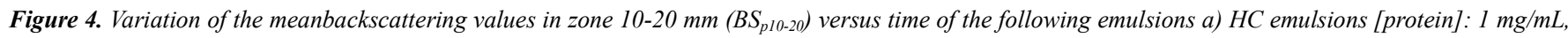
b) $\mathrm{HpH}$ emulsions[protein]: $1 \mathrm{mg} / \mathrm{mL}$, c) HC emulsions [protein]: $2 \mathrm{mg} / \mathrm{mL}$ and d) $\mathrm{HpH}$ emulsions[protein]: $2 \mathrm{mg} / \mathrm{mL} ; \mathrm{DH}=0 \%(-), b) \mathrm{DH}=1.8(--), c) \mathrm{DH}$ $=2.5(\ldots)$ and d) $\mathrm{DH}=6,0 \%(---)$.

\subsubsection{Creaming Stability Study}

According to [14] emulsions with a hyperbolic BS profile would have such deviations from the Stokes' Law that, despite affecting the creaming rate of the droplets, these would keep the expected trend where larger droplets cream faster than smaller ones. Contrastingly, for emulsions with a sigmoid BS profile, the extent and incidence of the deviations from the Stokes' Law would be such that the movement of the droplets during the first interval of the creaming process would be impeded, however, over time, the delaying effects would decrease the extent and incidence, so that the creaming rate would assume a similar behavior to the hyperbolic profiles. The $\mathrm{k}_{\mathrm{h}}$ value indicates the type of behavior regarding stability andk $\mathrm{s}_{\mathrm{s}}$ is an index of the delay of the creaming rate. The $\mathrm{BS}_{h}$ and $\mathrm{BS}_{\mathrm{s}}$ values determinethe extent to which each term contributes to the overall destabilization process. In that respect, the $\mathrm{BS}_{\mathrm{h}} / \mathrm{BS}_{\mathrm{s}}$ ratio is even more suitable [14].

Tables $3 \mathrm{a}$ and $\mathrm{b}$ show the k-values and \%BS respectively, for the studied emulsions under all the assayed conditions.

$\mathrm{HpH}$ emulsions showed sigmoid-shaped BS vs t curves under every assayed condition, whereas $\mathrm{HC}$ emulsions showed hyperbolic curves under every assayed condition, except when the protein concentration was $2 \mathrm{mg} / \mathrm{mL}$ with $\mathrm{DH}$ $0,1.8$ and $2.5 \%$, which had a sigmoid-shaped curve.

Emulsions with $P=1 \mathrm{mg} / \mathrm{mL}$ showed no significant differences of $\mathrm{Kh}$ values, ks values and \%BSs with different values of $\mathrm{DH}$, whereas those with $\mathrm{P}=2 \mathrm{mg} / \mathrm{mL}$ only showed a significant difference in $\mathrm{kh}$, where the value corresponding to DH 6\% was lower than the rest. This indicates that there was no influence of DH either on the rate or delay effect of the creaming process. When the protein concentration increased, the $\mathrm{kh}$ and $\mathrm{ks}$ values were significantly lower except for DH $6 \%$, where no significant difference in the kh value was found, whereas the \%BS values increased significantly. This indicates less tendency to cream and greater delay effect as concentration increases for $\mathrm{HpH}$.

The $\mathrm{HC}$ emulsions [protein] $=1 \mathrm{mg} / \mathrm{mL}$ showed a hyperbolic kinetic behavior for all the studied DHs, with no significant differences in $\mathrm{kh}$ values. The increase in protein concentration cause a shift in the kinetic behavior (from hyperbolic to sigmoid) for DH $0,1.8$ and $2.5 \%$ and the kh values of those DHs did not show significant differences from each other and were considerably lower than the corresponding to $\mathrm{DH} 6 \%$. In addition, the increase in concentration caused less of a tendency to creaming, since the ks values significantly decreased accordingly.

The way the hydrolysis was stopped significantly affected the creaming rate and the delay effect. The kh values corresponding to $\mathrm{HpH}$ emulsions were significantly lower than those of $\mathrm{HC}$ emulsions in every studied condition. The ks values of $\mathrm{HpH}$ were significantly lower than those of $\mathrm{HC}$, while the \%BSs were three time greater than those of $\mathrm{HC}$.

The factors that could affect delay process of the creaming rate (as predicted by Stokes' Law) and manifest as a sigmoid 
BS vs time profile are numerous:electrostatically charged droplets in the emulsion[18],[19], high effective density of the disperse phase [20], high apparent viscosities at low shear flow of the dispersing phase [21], [19], concentrated emulsions [22],[23], size and structure of the floccules within the emulsion [24],[25], [19], [26],[27] and polydisperse emulsions [28],[29],[30].

The surface electric charge, density and viscosity of the disperse phase were constant throughout the study, and therefore their delaying effect on the creaming rate must also have remained constant. The $\mathrm{HC}$ emulsions were those with the highest degree of flocculation and were also the only ones that showed a hyperbolic behavior. Then, even if the HC could have been forming floccules in an open-net structure, this would not have been able decrease the creaming process enough to generate a sigmoid behavior kinetics.

According to [27], creaming can be completely inhibited when a certain $\Phi_{c}$ value is surpassed, and this value depends on the polydispersion of the emulsion. Then, in the studied emulsions, the particle concentration could have been such that the effect of droplet concentration and polydispersion would not only have caused a decrease in the creaming rate, but it would have also delayed the movement of the larger droplets. The particle concentration and the droplet size interval decreased with the evolution of the creaming process, so that the degree of delay could become smaller while the creaming rate increased. The higher the particle concentration and degree of polydispersion, the greater the delay in the creaming rate was and hence the lower the $\mathrm{k}_{\mathrm{s}}$ value was, which describes the sigmoid behavior of the $\mathrm{RD}(\mathrm{t})$ vs $t$ curves. The principle behind the Turbiscan equipment is the multiple dispersion of light and the fact that the BS values increase as the particle size decreases and as the particle volume fraction increases[31]. In general, the emulsions which had a sigmoid-like kinetic behavior showed significantly higher $\mathrm{BS}_{\mathrm{p}(10-20) i}$ values than those emulsions with a hyperbolic behavior (Table 3). This agrees with the principle that the delay in the creaming rate depended on the droplet concentration and their size. Furthermore, the emulsions with a hyperbolic kinetic behavior had a tendency to cream from the start as aggregated floccules, something which probably went on during the creaming process and contributed to increase the creaming rate, thus counteracting other processes that would favor its delay.

Table 3. $K$-values and $\% B S$ of the studied emulsions.

a. $k$-values

\begin{tabular}{|c|c|c|c|c|}
\hline & [prot.] $=1 \mathrm{mg} / \mathrm{ml}$ & & [prot.] = $2 \mathrm{mg} / \mathrm{ml}$ & \\
\hline SPIH Stopping method and DH & $\mathrm{k}_{\mathrm{h}}$ & $\mathrm{k}_{\mathrm{s}}$ & $\mathrm{k}_{\mathrm{h}}$ & $\mathrm{k}_{\mathrm{s}}$ \\
\hline HC-DH $0 \%$ & $(1.3 \pm 0.08) \times 10^{-3}$ & & $(4.9 \pm 0.05) \times 10^{-4}$ & $(1.7 \pm 0.05) \times 10^{-2}$ \\
\hline HC-DH $1.8 \%$ & $(1.1 \pm 0.05) \times 10^{-3}$ & & $(4.4 \pm 0.05) \times 10^{-4}$ & $(1.6 \pm 0.05) \times 10^{-2}$ \\
\hline HC-DH $2.5 \%$ & $(1.2 \pm 0.04) \times 10^{-3}$ & & $(4.4 \pm 0.05) \times 10^{-4}$ & $(3.1 \pm 0.05) \times 10^{-2}$ \\
\hline HC-DH $6.0 \%$ & $(1.6 \pm 0.05) \times 10^{-3}$ & & $(1.9 \pm 0.05) \times 10^{-3}$ & \\
\hline HpH-DH 0\% & $(4.8 \pm 0.05) \times 10^{-4}$ & $(5.4 \pm 0.05) \times 10^{-3}$ & $(3.6 \pm 0.08) \times 10^{-5}$ & $(2.3 \pm 0,08) \times 10^{-3}$ \\
\hline HpH-DH 1.8\% & $(5.0 \pm 0.05) \times 10^{-4}$ & $(5.4 \pm 0.05) \times 10^{-3}$ & $(8.0 \pm 0.05) \times 10^{-5}$ & $(3.1 \pm 0.05) \times 10^{-3}$ \\
\hline $\mathrm{HpH}-\mathrm{DH} 6.0 \%$ & $(5.4 \pm 0.05) \times 10^{-4}$ & $(7.6 \pm 0.05) \times 10^{-3}$ & $(3.9 \pm 0.05) \times 10^{-4}$ & $(4.8 \pm 0.05) \times 10^{-3}$ \\
\hline
\end{tabular}

b. Ratios of $B S_{h}$ and $B S_{S}$ and $B S_{i}$.

\begin{tabular}{|c|c|c|c|c|c|c|}
\hline \multirow[b]{2}{*}{ SPIH Stopping method and DH } & \multicolumn{3}{|c|}{ [prot.] $=1 \mathrm{mg} / \mathrm{ml}$} & \multicolumn{3}{|c|}{ [prot.] $=2 \mathrm{mg} / \mathrm{ml}$} \\
\hline & $\% \mathrm{BSh}_{\mathrm{h}}$ & $\% \mathrm{BS}_{\mathrm{S}}$ & $\mathrm{BS}_{\mathrm{i}}$ & $\% \mathrm{BS}_{\mathrm{h}}$ & $\% \mathrm{BS}_{\mathrm{S}}$ & $\mathrm{BS}_{\mathrm{i}}$ \\
\hline HC-DH $0 \%$ & $1.00 *$ & & $44 \pm 1$ & $0.74 \pm 0.04$ & $0.26 \pm 0.04$ & $53 \pm 1$ \\
\hline HC-DH $1.8 \%$ & $1.00 *$ & & $47 \pm 1$ & $0.78 \pm 0.04$ & $0.22 \pm 0.04$ & $53 \pm 1$ \\
\hline HC-DH $2.5 \%$ & $1.00 *$ & & $45 \pm 2$ & $0.83 \pm 0.04$ & $0.17 \pm 0.04$ & $52 \pm 1$ \\
\hline HC-DH $6.0 \%$ & $1.00 *$ & & $29 \pm 2$ & $1.00 *$ & & $36 \pm 1$ \\
\hline HpH-DH 0\% & $0.44 \pm 0.01$ & $0.56 \pm 0.01$ & $54 \pm 1$ & $0.32 \pm 0.02$ & $0.68 \pm 0.02$ & $60 \pm 1$ \\
\hline HpH-DH 1.8\% & $0.46 \pm 0.01$ & $0.54 \pm 0.01$ & $55 \pm 2$ & $0.39 \pm 0.02$ & $0.61 \pm 0.02$ & $60 \pm 1$ \\
\hline HpH-DH $6.0 \%$ & $0.48 \pm 0.01$ & $0.52 \pm 0.01$ & $52 \pm 5$ & $0.33 \pm 0.02$ & $0.67 \pm 0.02$ & $55 \pm 5$ \\
\hline
\end{tabular}

* In the case of HC $(1 \mathrm{mg} / \mathrm{mL})$, the curve is not sigmoid and is described by equation 5 , consequently it has only one term and a single amplitude parameter, therefore its ratio is 1 and is reported in the $\% \mathrm{BSh}$ column.

\subsubsection{Stability of the Emulsion to Flocculation and Coalescence}

In Figures $3 \mathrm{~A}$ and $\mathrm{B}$, zone II shows that the cream phase remained after the oil droplets gathered-up on the top of the tube. In order to compare the cream phases of the different assayed emulsions, the BS vs. 1(tube height ) profiles shown in Figures 3A and B were divided into three zones: A, B and $\mathrm{C}$, corresponding to the lower, middle and higher parts of the cream phase respectively. The profile of several emulsions, represented in the different studied conditions (Figures $5 \mathrm{a}-\mathrm{f}$ ), show a peak in zone A, which, according to[15] can be ascribed to the build-up of small droplets with low creaming rate. In addition, another prominent peak appears in zone $\mathrm{C}$ as a result of the presence of foam in the emulsions. In the middle zone (zone B) of the cream phase, the drop in the BS profile may be regarded as the decrease of the number of droplets, mainly generated by coalescence or coalescence together with a flocculation process [15].

When the emulsions are prepared with proteins as their 
only emulsifying agent, in low concentrations and under static conditions, coalescence is a slow destabilization mechanism compared to creaming and flocculation [32]. Storing the emulsions under static conditions, at room temperature for 24 hours is considered to be enough to detect coalescence [15]. In the emulsions corresponding to Figures $5 \mathrm{a}, \mathrm{b}$ and e, zone $\mathrm{B}(50-53 \mathrm{~mm})$ shows a marked decrease in the BS profile after 24 hours relative to the profile after the first hour of destabilization, whereas the emulsions corresponding to the conditions of Figures $5 \mathrm{c}$, e and $\mathrm{f}$, do not show this decrease. These results may indicate that the first group of emulsions could have experienced a considerable droplet size increase during the first 24 hours of storage.
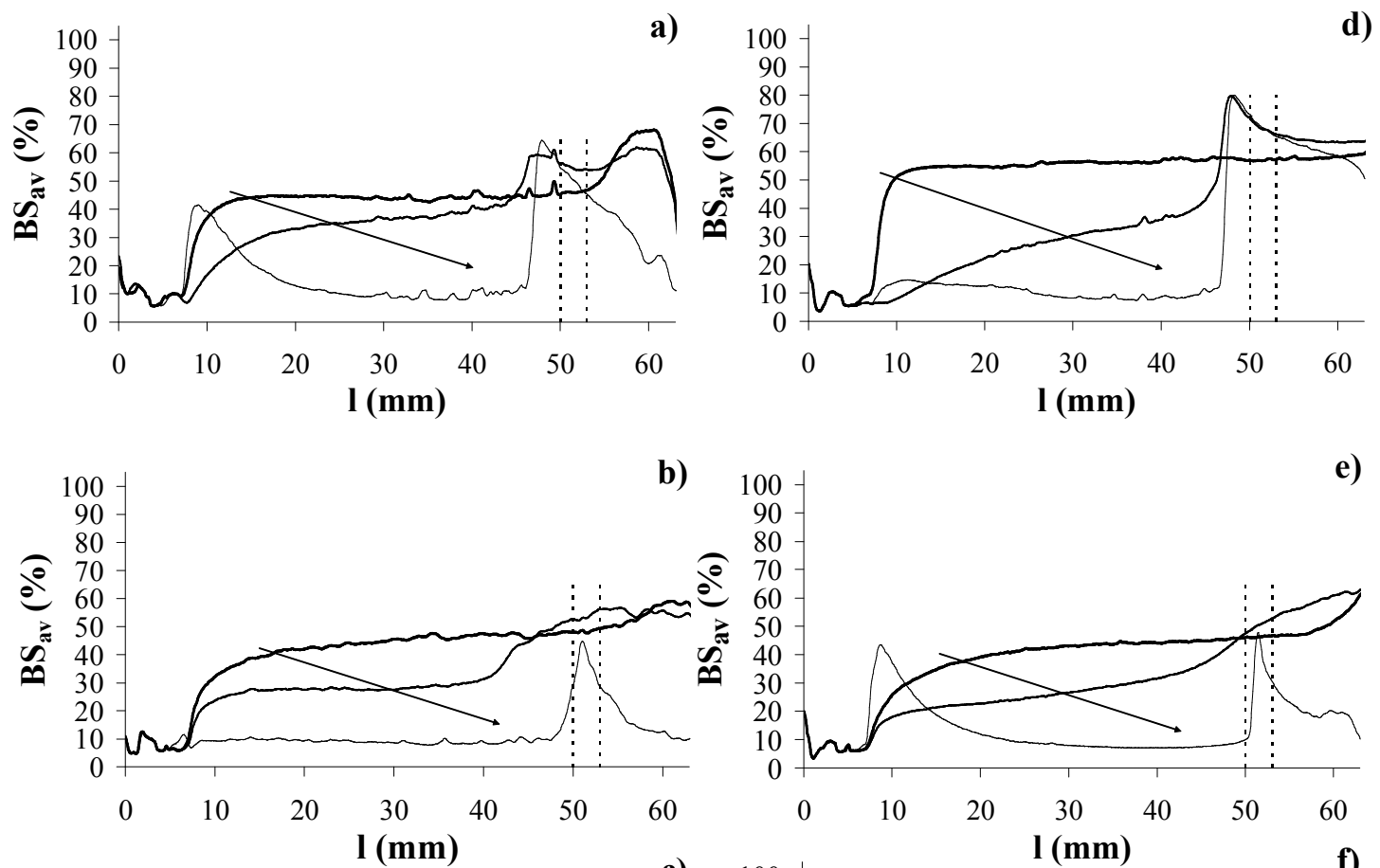

b) 100

e)
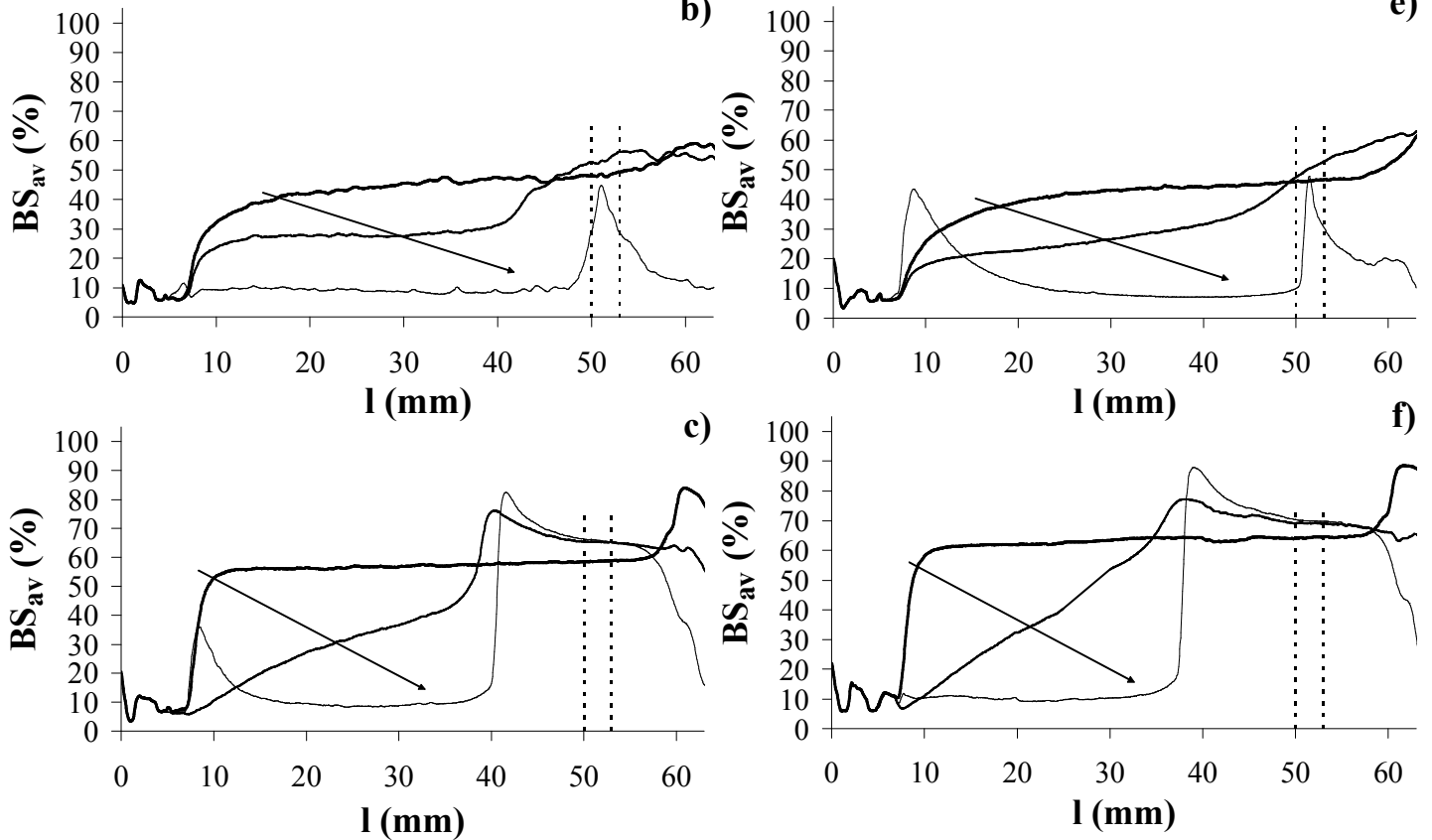

Figure 5. Backscattering profiles of emulsions prepared at 0 minutes, 60 minutes and 24 hours after the time of elaboration a) HC (DH $=0 \%$, [protein] $=1$ $m g / m L), b) H C(D H=6 \%,[p r o t e i n]=1 \mathrm{mg} / \mathrm{mL}), c) H p H(D H=0 \%,[p r o t e i n]=1 \mathrm{mg} / \mathrm{mL}), d) H C(D H=0 \%,[p r o t e i n]=2 \mathrm{mg} / \mathrm{mL}), e) \mathrm{HC}(\mathrm{DH}=6 \%$, [protein] $=2 \mathrm{mg} / \mathrm{mL}), f) \mathrm{HpH}(\mathrm{DH}=0 \%$, [protein] $=2 \mathrm{mg} / \mathrm{mL}$. The arrow indicates the change of the profile over time. The indicated zone corresponds to the $50-53$ mm interval.

\subsubsection{Destabilization Kinetics of the Cream Phase}

In order to analyze the destabilization kinetics of the cream phase, the $\mathrm{BS}_{\mathrm{p}}$ in zone $\mathrm{B}(50-53 \mathrm{~mm})$ taken from the $\mathrm{BS}$ profiles versus time ( 0 - 60 minutes) were recorded for all the assayed emulsions (Figures 6a-d). The time required for $\mathrm{BS}_{\mathrm{p}}$ to reach the maximum value $\left(\mathrm{BS}_{\mathrm{p}} \mathrm{max}\right.$.) is indicative of the balance between the build-up and decrease rates of the number of droplets. The lower values of $\mathrm{BS}_{\mathrm{p}} \mathrm{max}$., such as $\mathrm{HC}$ [protein] $=1 \mathrm{mg} / \mathrm{mL}$, indicate that during that time the decrease in the number of droplets, due to coalescence and/or flocculation was greater than the build-up of droplets due to the creaming process. In the case of $\mathrm{HpH}$ emulsions, under most of the assayed conditions the maximum BSp value was obtained at 60 minutes, which indicates a slow rate of formation of the stable cream phase. The two described situations are in line with the creaming destabilization behavior shown by both groups of emulsions.

The $\mathrm{D}(\%)$ values (Equation 5$)$ were obtained from the BS profiles. This parameter allowed the quantification of the overall destabilization of the cream phase since its formation until the end of its storage ( 24 hours). Since it is a $\mathrm{BS}_{\mathrm{p}}$ decrease index, associated with a lower particle number, it can be associated with coalescence and/or flocculation.

The D\% (BSp50-53) values are shown in Table 4 for all the assayed conditions. The prepared emulsions, under the 
different assayed conditions with HC, showed a considerable degree of destabilization, while those prepared by $\mathrm{HpH}$ were stable to flocculation and coalescence processes. The emulsions prepared byHC ([protein] $=1 \mathrm{mg} / \mathrm{mL}$ ) had a prevalence of particle inflow into the cream zone, whether flocculated or not, causing an increase of $\mathrm{BS}_{\mathrm{p} 50-53}$, peaking after 8 to 20 minutes. In the case of $\mathrm{DH}=0,1.8$ y $2.5 \%$, that value decreased as the degree of hydrolysis increased, whereas the degree of destabilization increased (Figures $5 \mathrm{a}, \mathrm{b}$ y e). For $\mathrm{DH} 6 \% \mathrm{BS}_{\mathrm{p} 50-53}$ it decreased from the beginning and it also displayed the highest $\mathrm{D} \%$ value.

According to [33], the stability of oil-in-water emulsions is mainly affected by the viscoelastic properties of the surfactant film, and the steric repulsion between the adsorbed surfactant layers, which in turn delays flocculation in the initial stages that leads to coalescence. As stated by [27] the partially hydrolyzed do not prevent coalescence as efficiently since they tend to form less viscoelastic and thinner interfacial layers, which break more easily. This could account for the increase of the degree of destabilization as $\mathrm{DH}$ rises, to such extent that $\mathrm{DH}=6 \%$ emulsions showed a decrease in $\mathrm{BS}_{\mathrm{p} 50-53}$ from the beginning. On the other hand, the probability of forming a breach in a given place of the membrane is higher as the area increases. Consequently, the greater the contact area between two droplets, the greater the coalescence rate. The coalescence rate therefore increases as the droplet size of an emulsion increases, or when the droplets are pushed against each other. This process takes place in very concentrated emulsions and cream layers [17], [19]. In the case of DH 6\%, larger droplets formed from the start (Table 1) which subsequently favored coalescence.

The HpH proteins had more flexibility to get placed at the interface, since they were previously dissociated and denatured by the low $\mathrm{pH}$, particularly the $\mathrm{AB}$ glycinin subunits. Additionally, having a greater interfacial protein concentration favored the steric repulsions and therefore made it less likely to flocculate. The greater interfacial protein concentration also provided more resistance to coalescence to the film. For DH 6\%, despite the high loss of $\beta$-conglycinin, which accounts for most of the stability of soy protein-derived emulsions [2], the aforementioned interfacial behavior was not affected. Therefore, most of the stability could be attributed mainly to the existence of glycinin as $\mathrm{AB}$ subunits.

The emulsions can become stable to coalescence when the thickness of the continuous interstitial phase is enough to prevent contact between the droplet films [27]. For this reason, a greater interstitial aqueous phase in the cream phase could reduce coalescence to a minimum [15]. In the measurements tubes, the actual sample height of the emulsion was about $53 \mathrm{~mm}(7 \mathrm{~mm}$ belong to the lower tube cap), from which about $40 \mathrm{~mm}$ correspond to the initial aqueous phase $(75 \%)$ and about $13 \mathrm{~mm}$ to the initial oil phase $(25 \%)$. Thus the limit between both phases should theoretically be at $47 \mathrm{~mm}$. In the $\mathrm{BS}_{\mathrm{p} 50-53} \mathrm{Vs}$. time plots of the emulsions prepared by $\mathrm{HpH}$ (Figures $5 \mathrm{c}$ and $\mathrm{f}$ ), the BS profile of the cream phase corresponding to 24 hours begins at $40 \mathrm{~mm}$, which indicates that the cream phase is highly hydrated, which could have contributed to the flocculation and coalescence stability. On the contrary, the profiles at 24 hours of the $\mathrm{HC}$ emulsions begin around $47 \mathrm{~mm}$, which indicates a poor hydration of the cream phase corresponding to 24 hours. The $\mathrm{HC}$ emulsions with a protein concentration of $2 \mathrm{mg} / \mathrm{mL}$, despite showing more destabilization as the degree of hydrolysis increased, had a significantly lower destabilization than those with a protein concentration pf 1 $\mathrm{mg} / \mathrm{mL}$. This lower tendency to flocculation/coalescence compared to [HAS-C] $=1 \mathrm{mg} / \mathrm{mL}$ can be ascribed to the fact that, quite likely, interfacial protein concentration was higher in this case and therefore the film was more resistant to coalescence due to prolonged contact.

The most notable difference in the formation of the studied emulsions was the lower $\mathrm{D}_{3.2}$ values of the $\mathrm{HC}$ emulsions. The higher degree of flocculation of the droplets in $\mathrm{HC}$ emulsions could mainly be a consequence of hydrophobic interactions, since soy proteins cannot undergo marked conformational changes at the interface [34], leading to some hydrophobic areas oriented towards the aqueous phase, enabling the interaction with other film proteins in neighboring droplets. Nevertheless, the droplets corresponding to the $\mathrm{HC} \mathrm{DH} 6 \%$ emulsions showed a lower degree of flocculation. During the formation of the emulsion, before the coalescence caused by collisions, flocculation is likely to occur and, depending on the resistance of the protein film, coalescence may or may not occur. Emulsions with DH6\% containing SDS showed a significantly higher $\mathrm{D}_{4.3}$ value (about three times higher) than the rest of the $\mathrm{HC}$ samples. This could be explained by their lower film resistance (due to a higher degree of hydrolysis) that rapidly turned flocculation into coalescence. One possible explanation for the differences is that the $\mathrm{HC}$ samples were adsorbed more rapidly and efficiently. However, the proteins of $\mathrm{HpH}$ samples were dissociated (lower molecular size), unfolded, and showed a higher surface $\mathrm{H}_{\mathrm{o}}[35]$, therefore they should have been adsorbed more rapidly and efficiently (or at least similarly) than the $\mathrm{HC}$ ones, but definitely not more slowly. The droplets formed with $\mathrm{HpH}$ showed a higher interfacial protein concentration and, consequently, considering that, they should have been more resistant to collision-mediated coalescence that may have occurred during homogenization. All evidence would suggest that $\mathrm{HpH}$ should have shown a better behavior during the formation of the emulsions. However, based on observations to date, the lower $\mathrm{D}_{3.2}$ of the $\mathrm{HC}$ emulsions could be a result of the formation of a membrane that is more resistant to coalescence, and this behavior could be linked to a higher interaction of proteins with the oil phase and with each other, conferring it with more cohesiveness.

On the other hand, in the cream phase the droplets of $\mathrm{HC}$ emulsions showed a remarkable degree of destabilization and a considerable degree of coalescence, while the $\mathrm{HpH}$ emulsions showed great stability and no coalescence was noted during the duration of the study. Although coalescence was a result of collisions and prolonged contact (in the cream 
phase), it is conceivable that a membrane capable of resisting the coalescence phenomenon in one scenario should be able to resist it in the other. From this observation it follows that the differences between the $\mathrm{D}_{3.2}$ of the $\mathrm{HC}$ and $\mathrm{HpH}$ emulsions should not be ascribed to the droplets' resistance to coalesce, given the collisions they experience during homogenization. One plausible explanation of the observed phenomenon is that whether a droplet is prone to break up during homogenization also depends on the emulsifying capacity to improve rheological and viscoelastic properties of the interfacial film, since it would make it less likely for the droplets to break up and give place to larger droplets than expected for a given equilibrium interfacial tension [36],[37],[38]. This is probably the case for droplets in $\mathrm{HpH}$ samples, which also agrees with their behavior in the cream

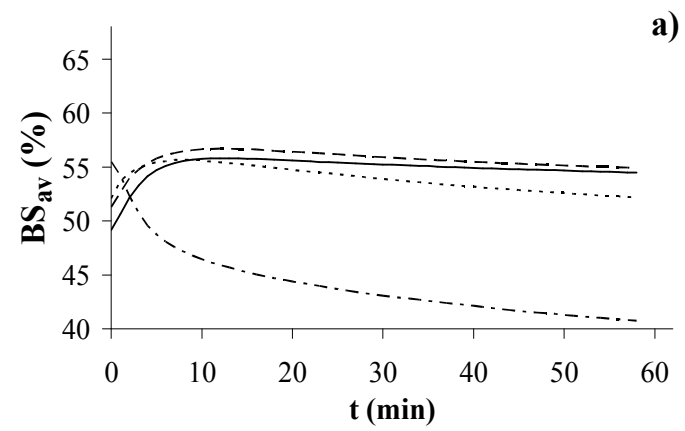

a)

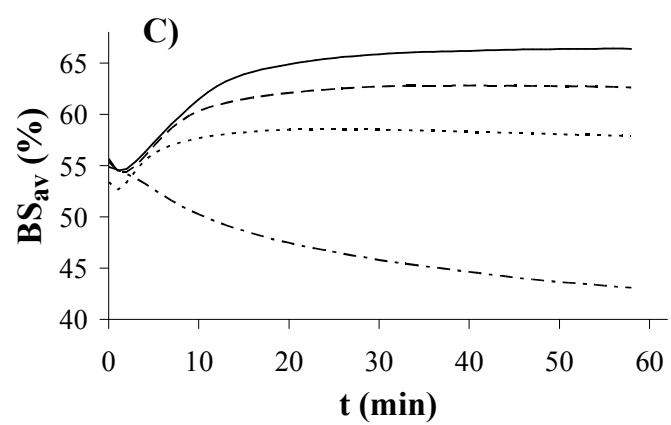

phase. In sum, there actually is agreement between the behavior of the droplets in the different emulsions with the formation, stability and properties that the proteins conferred to the interfacial films.

Table 4. Degree of destabilization $(D(\%))$ in the 50-53 mm zone.

\begin{tabular}{lll}
\hline Stopping method of SPIH and DH & [prot.] $=\mathbf{1} \mathbf{~ m g} / \mathbf{m l}$ [prot.] = $\mathbf{~ m g} / \mathbf{m l}$ \\
\hline HC-DH 0\% & $13 \pm 4$ & $1 \pm 1$ \\
HC-DH 1.8\% & $15 \pm 3$ & $9 \pm 2$ \\
HC-DH 2.5\% & $21 \pm 3$ & $17 \pm 3$ \\
HC-DH 6.0\% & $59 \pm 9$ & $47 \pm 9$ \\
HpH-DH 0\% & S & S \\
HpH-DH 1.8\% & S & S \\
HpH-DH 2.5\% & S & S \\
HpH-DH 6.0\% & S & S \\
\hline
\end{tabular}

S: stable

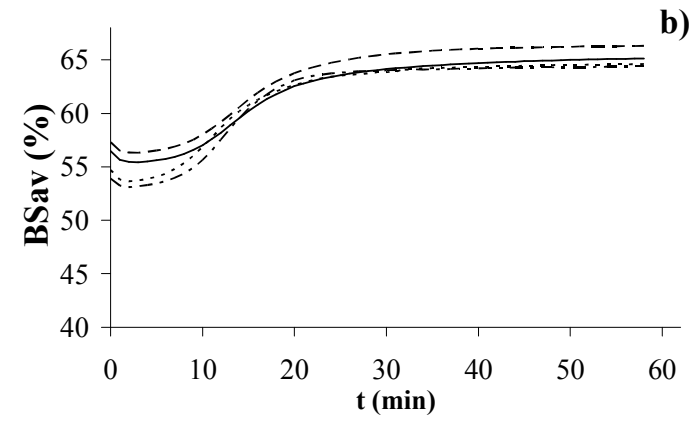

b)

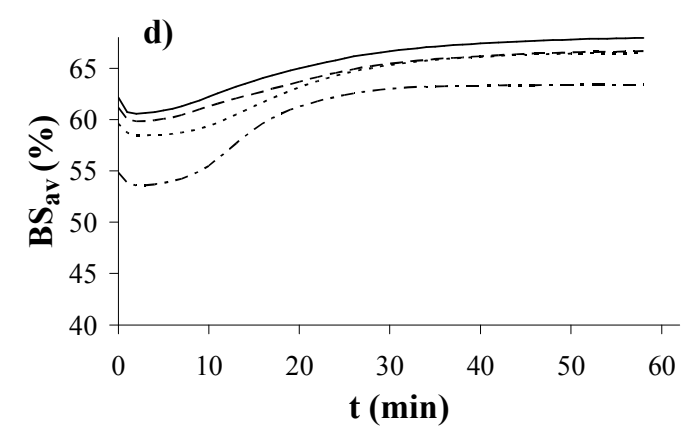

Figure 6. Variation of the meanbackscattering values in zone 50-53 mm (BS $\left.{ }_{p 50-53}\right)$ versus time for a) HC [protein]: $\left.\left.1 \mathrm{mg} / \mathrm{mL}, \mathrm{b}\right) \mathrm{HpH}[\mathrm{protein}]: 1 \mathrm{mg} / \mathrm{mL}, \mathrm{c}\right) \mathrm{HC}$ [protein]: $2 \mathrm{mg} / \mathrm{mL}, d$ ) HC [protein]: $2 \mathrm{mg} / \mathrm{mL}(\mathrm{DH}=0 \%(-), \mathrm{DH}=1.8(-), \mathrm{DH}=2.5$ (...) and $\mathrm{DH}=6.0 \%(-.-)$.

\section{Conclusions}

The obtained results show that a very slight hydrolysis (DH 1.8 and 2.5\%) does not have a beneficial effect on the emulsifying properties of those hydrolysates where the enzyme activity was stopped by freezing. Only the HC samples with DH 6\% showed changes in their properties, which were actually detrimental. The detrimental effect of DH $6 \%$ on the emulsifying ability was reflected on the greater obtained droplet size $\left(\mathrm{D}_{4.3}\right)$ and on the stability at greater $\mathrm{D} \%$ values. The emulsions that were prepared with $\mathrm{HC} \mathrm{DH} 6 \%$ showed a greater tendency to coalesce due to the collisions that took place during formation, and through contact with the cream phase. In every case, the detrimental effect was ascribed to the loss of molecular size, which did not allow the formation of a film with suitable viscoelastic and cohesive properties. In particular, these negative effects may be attributed to the hydrolysis of $\beta$-conglycinin compared to the hydrolysis of glycinin. In the case of emulsions then, $\beta$-conclycinin is the one that displays the best emulsifying properties.

The SPIHs where the enzyme activity was stopped by lowering the $\mathrm{pH}$ showed better emulsifying properties that those that were untreated. The emulsions derived from them were the most stable against creaming, flocculation and coalescence. In every case, the positive effect was ascribed to the dissociation and denaturalization of soy proteins by the $\mathrm{pH}$ treatment, which favored the formation of a film at the interface with good cohesive and viscoelastic properties. Moreover, the fact that these emulsions had higher $\mathrm{D}_{3.2}$ and $\mathrm{D}_{4.3}$ values was also correlated to the characteristics of the formed film. As previously mentioned a $\mathrm{DH} 6 \%$ had 
detrimental effects on the properties, but this effect was not observed in the case of HpHs. Despite $\beta$-conglycinin dissociating due to the low $\mathrm{pH}$ treatment, in that case of $\mathrm{DH}$ $6 \%$ it underwent extensive hydrolysis which was responsible for the negative effect on the emulsifying properties. Consequently, those enhanced film properties which lead to superior functional properties can be attributed mainly to the dissociation of glycinin into its $\mathrm{AB}$ subunits and their denaturalization.

The method used to stop the papain hydrolysis reaction of the soy proteins in the isolates was a key aspect in the structural and emulsifying properties of the obtained products.

The hydrolysis did not have a beneficial effect on the emulsifying properties of the hydrolysates that were stopped by freezing. A $6 \%$ degree of hydrolysis negatively affected the emulsifying properties of the HCs.

Stopping the hydrolysis reaction by lowering to $\mathrm{pH} 2$ made a significant improvement of the emulsifying properties of the isolates, for all the studied degrees of hydrolysis.

\section{Acknowledgements}

Financial support was granted by CSIC (Comisión Sectorial de Investigación Científica) of Universidad de la República, PDT (Plan de Desarrollo Tecnológico) of the Ministry of Culture and Education (Grant S/C/BE/06/15) and PEDECIBA (Plan de Desarrollo de las Ciencias Básicas), Uruguay.

\section{References}

[1] Van Vliet, T.; Martin, A. H.; Bos, M. A. 2002. Gelation and interfacial behaviour of vegetable proteins. Current Opininion in Colloid \& Interface Science. 7, 462 - 468.

[2] Utsumi, S.; Matsumura, Y.; Mori, T. 1997. Structure-Function relationships of soy proteins. In Food Proteins and Their Applications. Edited by Damodaran, S. and Paraf, A. Marcel Dekker, New York. 257-291.

[3] Schwenke, K. D. 2001. Reflections about the functional potential of legume proteins. A review. Nahrung. 45, 377-381.

[4] Were, L.; Hettiarachchy, N. S.; Kalapathy, U. 1997. Modified Soy proteins with improved foaming and water hydration properties. Journal of Food Science. 62, 821-824.

[5] Wu, W.; Hettiarachchy, N. S.; Qi, M. 1998. Hydrophobicity, solubility, and emulsifying properties of soy protein peptides prepared by papain modification and ultrafiltration. Journal of the American Oil of Chemists' Society. 75, 845-850.

[6] Petruccelli, S.; Añón, M. C. 1994. The relationship between the method of preparation and the structural and functional properties of soy protein isolates. Part I: Structural and hydration properties. Journal of Agriculture and Food Chemistry. 42, 2161-2169.

[7] Adler-Nissen, J. 1976. Enzymic hydrolysis of proteins for increased solubility. Journal of Agricultural and Food Chemistry. 24, $1090-1093$.

[8] Cayot, P.; Tainturier, G. 1997. The quantification of protein amino groups by the trinitrobenzenesulfonic acid method: a reexamination. Analytical Biochemistry. 249, 184-200.

[9] Anton, M.; Beaumal, V.; Brossard, C.; Llamas, G.; le Denmat, M. (2002). Droplet flocculation and physical stability of oilin-water emulsions prepared with hen egg yolk. En Food emulsions and dispersions. Edited by Anton, M. Research Signpost, Kerala, India. 15-28.

[10] Patton, S.; Huston, G. E. (1986). A method for isolation of milk fat globules. Lipids, 21, 170-174.

[11] Puppo, M.C.; Speroni, F.; Chapleau, N.; de Lamballerie, M.; Añón, M. C.; Antón, M. 2005. Effect of high-pressure treatment on emulsifying properties of soybean proteins. Food Hydrocolloids. 19, 289-296.

[12] Markwell, M. A.; Haas, S. M.; Bieber, L. L.; Tolbert, N. E. 1978. A modification of the Lowry procedure to simplify protein determination in membrane and lipoprotein samples. Analytical Biochemistry. 87, 206-210.

[13] Palazolo, G. G., Sorgentini, D. A.; Wagner, J. R. 2004. Emulsifying properties and surface behavior of native and denatured whey soy proteins in comparison with other proteins. Creaming stability of oil-in water emulsions. Journal of the American Oil of Chemists' Society. 81, 625-632.

[14] Panizzolo, L. A.; Mussio, L. E.; Añón, M. C. 2015. A kinetic for describing the creaming of protein-stabilized $\mathrm{o} / \mathrm{w}$ emulsions by multiple light scattering. Journal of Food Science and Engineering. (in press).

[15] Palazolo, G. G.; Sorgentini, D. A.; Wagner, J. R. 2005. Coalescence and flocculation in $\mathrm{o} / \mathrm{w}$ emulsions of native and denatured whey soy proteins in comparison with soy protein isolates. Food Hydrocolloids. 19, 595-604.

[16] Walstra, P. 1993. Principles of emulsion formation. Chemical Engineering Science. 48,333-349.

[17] Relkin, P.; Sourdet, S. 2005. Factors affecting fat droplet aggregation in whipped frozen protein-stabilized emulsions.Food Hydrocolloids. 19, 503-511.

[18] Dickinson, E.; Stainsby, G. 1982. Colloids in Food. Applied Science Publishers, London, UK.

[19] Walstra, P. 1996. Emulsion stability. En Encyclopedia of Emulsion Technology.Editado por Becher, P. Marcel Dekker, New York. 4, 1-62.

[20] Tan, C. T. 1990. Beverage emulsion. En Food emulsion. Edited by Friberg, S. and Larsson, K. Marcel Dekker, Inc., New York.

[21] Dickinson, E. 1992. An introduction to food colloids. Oxford Science Publications, Oxford, UK.

[22] Hunter, R. J. 1989. Rheology of Colloidal Dispersions. In: Foundations of Colloid Science. Oxford University Press, New York. 2, chapter 18.

[23] Pinfield, V. J.; Dickinson, E.; Povey, M. J. W. 1994. Modelling of Concentration Profiles and Ultrasound Velocity Profiles in a Creaming Emulsion: Importance of Scattering Effects. Journal of Colloid and Interface Science. 166, 363-374.

[24] Bremer, L. G. B. 1992. Theoretical and experimental study of the fractal nature of the structure of particle gels. Thesis, Wageningen Agricultural University, The Netherlands. 
[25] Bremer, L. G. B.; Bijsterbosch, B. H.; Walstra, P.; van Vliet, T. 1993. Formation, properties and fractal structure of particle gels. Advances in Protein Chemistry. 46, 117-128.

[26] Pinfield, V. J.; Dickinson, E.; Povey, M. J. W. 1997. Modelling of combined creaming and flocculation in emulsions. Journal of Colloid and Interface Science. 186, 80-89.

[27] Mc Clements, D. J. 1999. Food emulsions. Principles, practice and techniques. CRC Press. USA.

[28] Melik, D. H.; Fogler, H. S. 1988. Fundamentals of colloidal stability. En: Quiescent media. Encyclopedia of Emulsion Technology. Editado por Becher, P. Marcel Dekker, New York. 3, 3-78.

[29] Das, A. K.; Ghosh, P. K. 1990. Concentrated emulsions. Investigation of polydispersity and droplet distortion and their effect on volume fraction and interfacial area. Langmuir. 6, 1668-1675.

[30] Dukhin, S.; Sjøblom, J. 1996. Kinetics of brownian and gravitational coagulation in dilute emulsions. En: Emulsions and emulsions stability. Edited by Sjøblom, J. Marcel Dekker, New York. 41-180.

[31] Mengual, O.; Meunier, G.; Cayré, I.; Puech, K.; Snabre, P. 1999. TURBISCAN MA 2000: multiple light scattering measurement for concentrated emulsion and suspension instability analysis. Talanta. 50, 445-456.
[32] Britten, M.; Giroux, H. J. (1991). Coalescence index of protein-stabilised emulsions. Journal of Food Science. 56, 792-795.

[33] Damodaran, S. 2005. Protein stabilization of emulsions and foams. Journal of Food Science. 70, $54-66$.

[34] Damodaran, S. 1997. Protein-stabilized foams and emulsions. In: Food proteins and their applications. Edited by Damodaran, S. and Paraf, A. Marcel Dekker, New York. 57-110.

[35] Panizzolo, L. A.; Añón, M. C. 2015. Foaming properties of soy protein isolate hydrolysates. Journal of Food and Nutrition Sciences. (in press).

[36] Lucassen-Reynders, E. H.; Kuijpers, K. A. 1992. The role of interfacial properties in emulsification. Colloids Surfaces. 65, 175-184.

[37] Janssen, J. J. M.; Boon, A.; Agterof, W. G. 1994. Influence of dynamic interfacial properties on droplet breakup in simple shear flow. AIChE Journal. 40, 1929-1939.

[38] Williams, A.; Janssen, J. J. M.; Prins, A. 1997. Behaviour of droplets in simple shear flow in the presence of a protein emulsifier Colloids and Surfaces A: Physicochemical and Engineering Aspects. 125, 189-200. 